\title{
Progress in retail led regeneration: Implications for decision-makers
}

Received (in revised form): 11 October 2005

\section{Paul Instone}

is a senior planning consultant at Scott Wilson and a member of the Royal Town Planning Institute. He specialises in retail and employment issues and provides technical expertise to both public clients and private sector operators.

\section{Glyn Roberts}

has recently become Development Director with the North Staffordshire Regeneration Partnership. Prior to this he was Technical Director (Planning and Regeneration) with major planning consultancy Scott Wilson, managing planning teams whose specialisms include retail research, regeneration, masterplanning/urban design, sustainability, development plans and planning applications/appeals. Prior to joining Scott Wilson Roberts he was Director of the North Liverpool Partnership and Chief Planner of the Central Manchester Urban Development Corporation.

\begin{abstract}
This paper provides a qualitative assessment of retailing trends since World War II and describes how the location and characteristics of retail provision have created disadvantages for certain sections of society. The paper examines the polarisation of retail provision and assesses the implications of declining local centre shopping facilities for certain sections of the community. The paper provides a critique of recent 'retail-led regeneration' schemes, and assesses whether these schemes exacerbate the problems of weak local markets. In turn, the research examines whether these schemes are the most appropriate mechanism to meet the wider economic, social, physical and environmental regeneration challenges raised by service deficiencies within these communities.
\end{abstract}

\section{Keywords:}

retail, regeneration, local centres, network, ethnic retail, polarisation

Journal of Retail and Leisure Property (2006) 5, 148-161.

doi:10.1057/palgrave.rlp.5100009

Paul Instone

Senior Planning Consultant 17 th Floor, McLaren House 35 Dale End Birmingham B4 $7 \mathrm{LN}$, UK Tel: + 441212148240 Fax: + 441212121938 E-mail: paul.instone@scottwilson.com

\section{INTRODUCTION}

Retail activities and shopping lie at the heart of the provision of goods and services to communities within urban areas in market economies. As a result retail development is often used to underpin regeneration schemes providing a catalyst for the wider physical development of such urban areas as they age and come forward for renewal. However, while it is 
evident that high profile retail schemes can bring physical regeneration to an area, it must also be considered that these schemes are often located within major city or town centres. They may accelerate the continuing demise of local retail and service facilities in the inner urban areas or smaller/weaker centres nearby. Private investment in strong new retail activity in a city centre or major town centre may in due course lead to the necessity for public investment in addressing social or economic problems exacerbated by weak local retail facilities in inner urban or suburban centres within the wider catchment.

While many of these larger city centre and town centre retail-led regeneration schemes are recognised as major flagship developments, creating jobs and bringing development to sometimes run-down areas, the schemes may also involve a continued flow of expenditure away from local service centres. This, in turn, may exacerbate the continued decline in local service provision compounding the social disadvantages of underserved communities.

This paper tracks the effects of recent retail trends and assesses the extent to which major retail-led regeneration promotes physical, economic and social regeneration. It also seeks to establish whether these high profile schemes are always the most appropriate way of delivering social and economic objectives to urban areas and, when they are justified, whether they can be approached in ways that produce a more balanced set of socio-economic impacts and benefits.

\section{CHRONOLOGY OF RETAIL DEVELOPMENT AND POLICY CONTEXT}

The location and design of retail development at any one time represents a response to a multitude of factors including consumer demand and mobility, the prevailing public policy context, structural change within retailing and changing operator requirements. Over the last century the location and characteristics of the retail offer of cities, towns and local centres have varied significantly as these factors have changed.

Traditionally retail provision has been located in town and local centres providing extensive service provision and employment opportunities for local communities. However, as household car use has grown rapidly and as retail operator requirements have changed as a result, there has been a move away from traditional local shopping provision, which has resulted in a decline of historic localised small-scale high street independent retail offers.

This shift away from local independent high street retail offers has been a gradual result of retail development trends over the last century. Traditional pre-war high street retail patterns, such as Prince's Street Edinburgh, provided a permeable, traditional High Street retail environment (Figure 1).

These traditional shopping streets began to be replaced or supplemented in the late 1950s by open 'shopping precincts'. Precinct developments were intended to provide functionality for shoppers and retailers alike, and were based on formalised street patterns and 1950s/ 1960s architecture. These retail centres, such as Exeter, generally lacked 
the organic nature of the traditional high street built environment but were based upon traditional high street and local centre principles (Figure 2).

From the 1960s onwards, covered shopping facilities began to appear within town centres. Examples of these were the Bullring in Birmingham, the Tricorn in Portsmouth and the Arndale in Manchester (Figure 3). This type of shopping provision was located within large buildings providing shoppers with a sheltered shopping environment and introduced the concept of manipulating shopping patterns through anchors. These covered shopping facilities were often monolithic, failing to integrate with the wider street pattern and retail provision of the town centre.

As levels of car ownership began to increase between the 1970s and 1990s out of town retail centres such as the Trafford Centre and the Metro Centre were built, providing a wide range of retail goods in out of centre locations that are easily accessible by car. These out of town retail centres operate in direct competition with town centres, providing a range and type of goods that is comparable to town centre offers. This type of retail offer is heavily dependent on the car-borne shopper, and relatively inaccessible to people with limited mobility and access to transport (Figure 4).

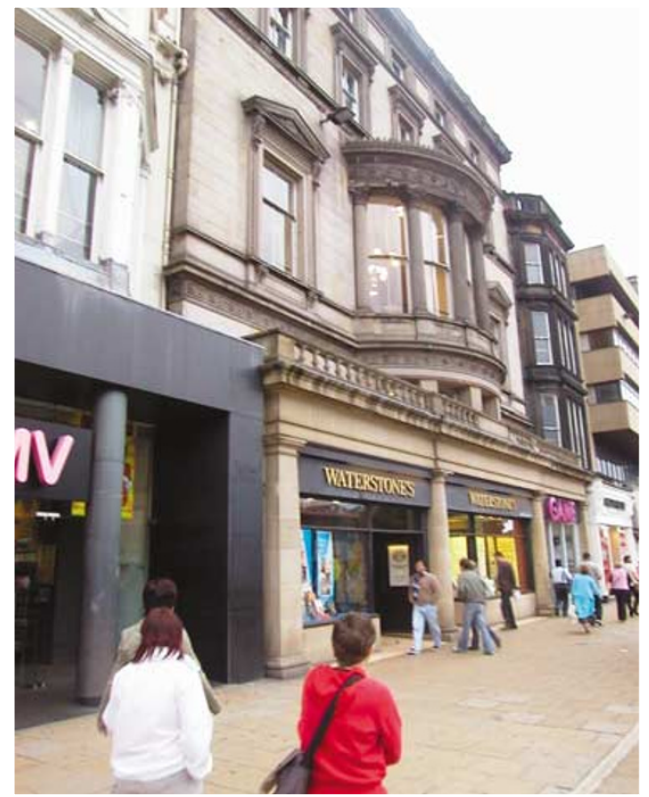

Figure I: Princes Street, Edinburgh
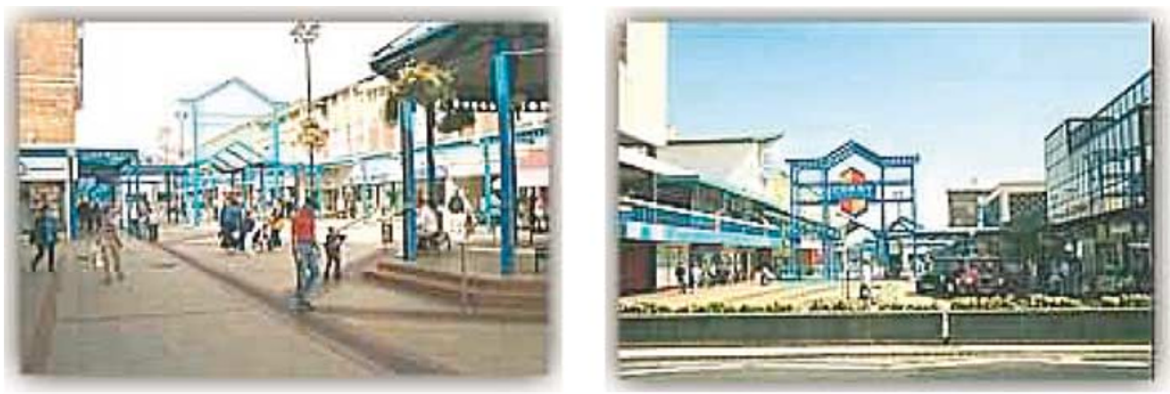

Figure 2: Corby town centre (Corby: Source — www.northamptonshire.co.uk) 


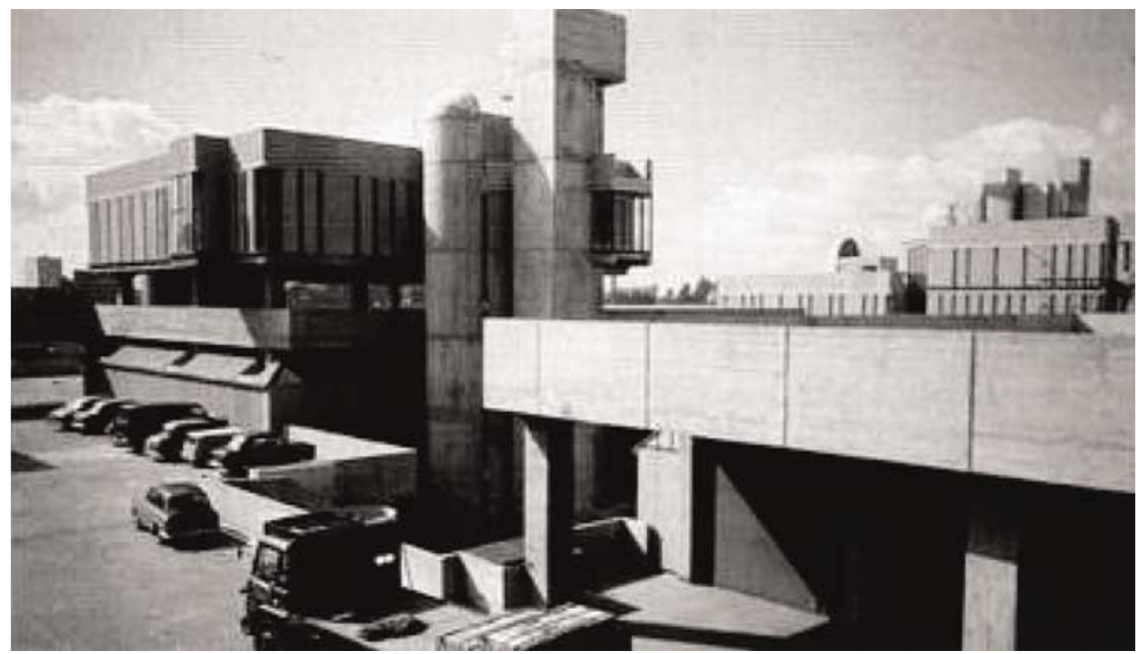

Figure 3: The Tricorn, Portsmouth: Source — Portsmouth Society
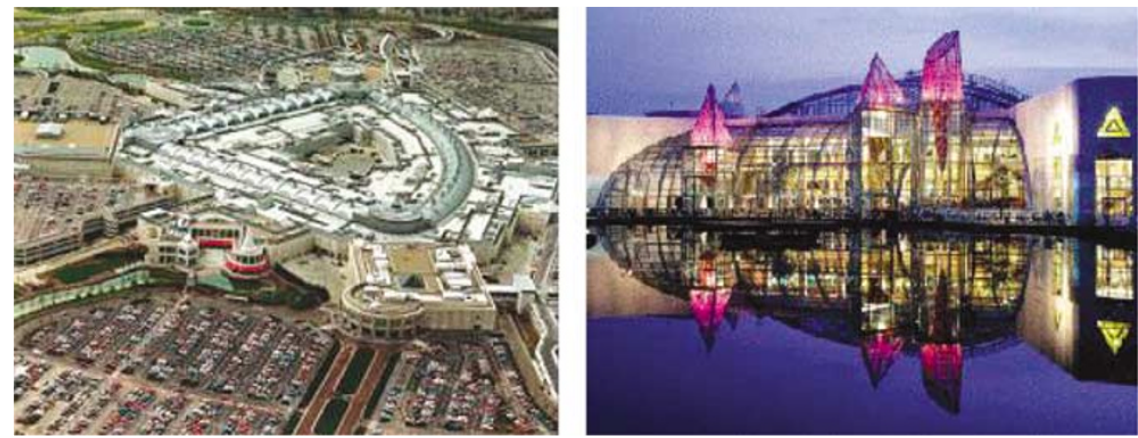

Figure 4: Bluewater Shopping Centre, Kent: Source - www.integer-softwear.co.uk

It was also during this period that large format supermarkets/ superstores began to develop. These stores which are primarily located in out-of-centre locations are easily accessible by car and operate in competition with local centre retail provision.

Following the introduction of Planning Policy Guidance Note 6: Town Centres and Retail Developments (1996) (PPG6) ${ }^{2}$ which included the sequential test for retail development, there was a move away from out of town retail developments and a concentration of retail provision within established town centres. Developments such as the new Bullring in Birmingham (Figure 5) and Selfridges in Manchester have provided high-quality shopping facilities within established higher-order town centres. These schemes incorporate large elements of natural lighting linking into the wider town centre built environment.

It is noticeable that over this period retail provision has been concentrated within established centres or out-of-centre locations, which are relatively high within the retail hierarchy. At the same time, as a result of this polarisation of retail provision there has been a decline in retail provision within traditional local centres.

The basic economic principles of market capacity and quantitative need demonstrate why one element of the retail provision may contract as another element expands. The population within a given area has a relatively fixed spending power. Although this spending power increases 


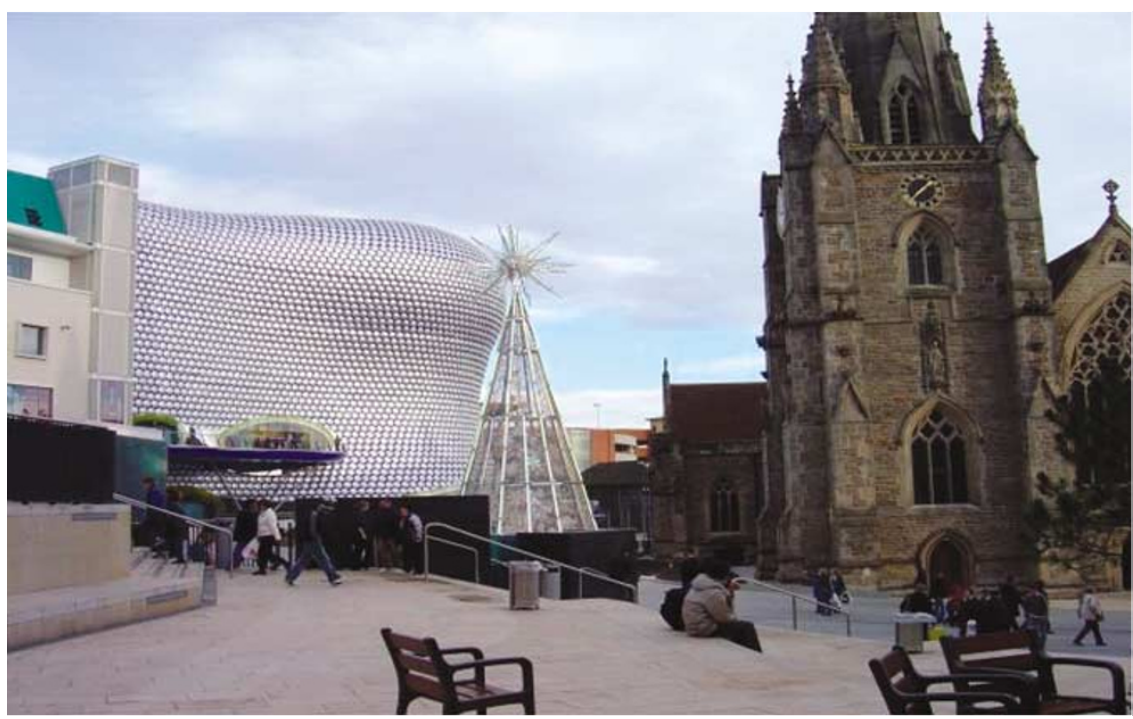

Figure 5: Selfridges, Birmingham: Source - www.birminghamuk.com

gradually over time, at any one point it is only capable of supporting a finite amount of retail floorspace. Therefore, as out-of-centre retailing increased in dominance from the 1980s onwards, the available proportion of expenditure flowing to town and local centres has decreased as a relative proportion of overall expenditure (and in some cases will have decreased in absolute terms when adjusted for inflation).

Concerns were raised from the 1960s onwards regarding the maintenance of the role and functions of traditional town and local centres - and therefore provision for the needs of the communities they served. Initially local centres were threatened by the development of the monolithic city centre retail structures described above such as the 1960s Plymouth Tricorn Centre and the old Birmingham Bull Ring Centre. While these facilities were at least central and accessible to low-income communities by public transport, even greater concerns were subsequently raised by the growth of out-of-town retail centres such as the Meadowhall Centre in Sheffield and the Metro Centre in Gateshead between the 1970s and 1990s. The trend towards such regional and sub-regional centres was paralled by the development of food and convenience superstores, many of which were out-of-centre and could only be accessed by car rather than by public transport. The new large format stores sold a diverse range of convenience and bulky goods and competed head-on with smaller, more traditional town centre and local centre retailers.

As the retail offer in out-of-centre locations increased, catering for the needs of car-borne shoppers from the more affluent sections of society, the retail offer within traditional high streets diminished in terms of both the diversity and quantity of the retail offer, raising serious implications for the communities that these centres serve.

The location trends of retail provision resulted in a polarisation of shopping behaviour, with less mobile shoppers becoming the primary 'main purchases' market for traditional retail facilities and other more 
mobile consumers using local retail provision chiefly for 'top-up shopping'. Relatively disadvantaged and less mobile sections of the community including the elderly, young, unemployed and sick have had little choice but to shop in local centres: the outcome is inequitable distribution of goods and services with limited consumer choice for certain sections of society.

As local centres have become increasingly reliant on a less affluent cross section of society, the long-term economic health of such centres has often become undermined as the expenditure attracted to them diminishes (often in both relative and absolute terms). Despite this apparently negative overall pattern, the private sector has responded to the polarised consumer profile by exploiting market niche opportunities. Firms such as Aldi, Lidl and Sommerfield have been prepared to locate within some lower-income neighbourhoods - although not in some of the most deprived areas experiencing depopulation. In addition, the main out-of town or edge-of town centre supermarkets including Tesco and Sainsbury's have opened local 'top-up' stores in town and city centres to provide for smaller-scale niche local shopping needs.

Whilst planning policy guidance in the late 1980s and early 1990s had regard to the vitality and viability of town and local centres, an emphasis also existed on facilitating competition between different types of shopping provision. One of the key advice notes within Planning Policy Guidance: Town Centres and Retail Developments $1993^{1}$ stated:
'the planning system should continue to facilitate competition between different types of shopping provision, by avoiding unnecessary regulation of shopping development, while taking account of the important contribution retail activity can make to securing the vitality and viability of town centres and villages.'

While the important role of town and village centres was recognised, it was not until 1996, and the advent of the sequential test within revised Planning Policy Guidance 6: Town Centres and Retail Developments (1996) (PPG6) that the emphasis on promoting town centres was established. This national policy has recently been up-dated by Planning Policy Statement 6: Planning for Town Centres (2005). ${ }^{3}$

The introduction of the sequential test into planning policy, requiring the most central locations to be taken up as a priority over more peripheral locations - alongside the fact that 'need' does not have to be proven for town centre schemes - has undoubtedly helped to concentrate new retail development within major centres and edge-of-centre locations. In conjunction with the policy shift towards enhancement of the vitality and viability of established centres, local authorities and town centre partnerships have sought to improve the competitiveness of many town centres through initiatives such as the appointment of town centre managers, the emergence of town centres Business Improvement Districts, pedestrianisation and traffic-calming schemes and increased car parking provision. Alongside these initiatives there has also been an increased focus on exploitation of retail development as a catalyst for regeneration in order to enhance the vitality and viability of established 
centres, in turn, increasing their ability to compete with out-of-centre retail offer.

\section{RETAIL-LED REGENERATION SCHEMES}

There have been a number of high profile retail schemes in recent years, which have been perceived by commentators as providing a catalyst for 'regeneration'. This retail investment has taken many forms including.

- Large-scale remodelling for example, Arndale Centre, Manchester

- Re-development and reinvestment for example, Bull Ring, Birmingham, Manchester City Centre redevelopment post IRA bomb

- Retail extensions to established centres for example, Liverpool

- Individual retail unit investment for example, French Connection, Manchester City Centre

- Business Improvement Districts (BIDs) for example, CVONE, Coventry and Paddington, London

When considering the regeneration benefits of these schemes it is important to assess the physical, environmental, economic and social implications of the development. High profile schemes such as the redevelopment of Manchester City Centre and Bull Ring redevelopment have attracted major retail brands to large established regional city centres. While the physical improvements to the built form that these schemes create are often apparent and easily visible, the wider potential affects of such schemes - both to the economy and the wider retail network - are often less transparent and it is important to consider the key elements of regeneration in turn.

While it is apparent that these schemes have had positive regeneration benefits on major regional and sub-regional urban centres, it is also evident that these developments support, and are in turn supported by, the continued 'march of the brand' - nationalised or global brands supplied through national or international multiple retail outlets operating on a directly-managed or franchised basis. We should therefore consider whether these flagship schemes are also drivers of the continuation of the demise of the retail offers within local centres together with the contraction of independent retailers within these local centres.

When considering this question, it must be recognised that retail goods are provided within a hierarchy and network of centres, and each of these centres has a role and function that meets a different consumer requirement. While it is clear that higher-order centres provide a different retail function to local centres, it is still evident that there are market overlap and 'domino' effects. As the dominance (and retail offer) of higher-order centres increase, these higher-order centres - taken together with other newer forms of retailing such as superstores and the internet attract an increased proportion of expenditure, albeit from a largercatchment area. As a result, as these effects works through the operation of the whole retail network, the overall 'gravity shift' may result in a loss of expenditure attributed to lower-order centres within the retail hierarchy, which may in turn undermine the vitality and viability of inner 
urban/suburban centres and former market towns adjoining the city or conurbation.

As a consequence, as increased retail provision is concentrated within larger centres, an element of local demand is diverted away from local centre capacity and the resultant relocations and closures will weaken local centres. This situation is exacerbated by competition from major supermarket chains and edge-of-town stores which are providing an extended range of convenience and comparison goods competing with local centres. The trend towards supermarkets selling comparison goods, for example, Asda-Walmart, has accelerated in recent years. In addition, the internet is creating additional competition, especially in some of the comparison goods sectors.

This decline in local retail provision has significant consequences for lower-income communities with low levels of car ownership as well as for the demographic sections of society that have limited mobility, access to cars or computers. Together with the deterrent visual effects of retail vacancy within local high streets and local precincts, there are sometimes wider adverse implications for a significant proportion of urban and rural communities. These may include a reduced choice of local shops together with diminished local employment opportunities in the retail sector, contributing to exacerbated social exclusion. In addition, polarisation of the retail offer generates a need to travel, undermining wider government objectives to encourage sustainability.

A good example of this situation exists in North Liverpool where local centres close to Scotland Road and Anfield football ground have been adversely affected by a combination of factors including the growth of City Centre retailing, car-borne supermarket and edge-of-town retail competition and demographic changes.

In a very deprived community of over 70,000 population where fewer than $20 \%$ of households have access to a car, residents have to travel further to access city centre comparison stores and use taxis to access supermarkets for food. Local shopping parades and corner shops have been decimated and the formerly famous 'Paddy's Market' is no longer held in the heart of the community. This is not to suggest that there should be a return to some imaginary 'golden age of local shopping'. What is required for the future is a retail network that provides 21 st century choice in a wide range of goods and services. However, such choice needs to be accessible to a wide range of households by sustainable means.

In conjunction with this centralisation of retail provision and the decline of retail provision within local centres, there is increased outflow of expenditure from local centres to larger higher order centres as larger branded multiple outlets in the larger centres increasingly capture business from smaller independent businesses in local suburban centres — reflecting the willingness and ability of many (but not all) consumers to travel further for a choice of cost and quality in goods and services.

This undermining of local centres is recognised by the policy community and there has been a recent policy appreciation of the need to rebalance the network of centres. Planning Policy Statement 6: Planning 
for Town Centres (2005), which provides the planning policy framework for town centre planning, states that:

'In defining their objectives, regional planning bodies and local planning authorities should consider whether there is a need to rebalance the network of centres to ensure that it is not overly dominated by the largest centres, that there is a more even distribution of town centre uses, and that people's everyday needs are met at the local level. In considering the development of the network and hierarchy, regional planning bodies and local planning authorities should consider:

- whether there is a need to avoid an over-concentration of growth in the higher order centres;

- the need for investment and growth to strengthen other centres, especially those needing regeneration; and

- the need to address deficiencies in the network by promoting centres to function at a higher level in the hierarchy or designating new centres.'

It is clear that it is an intention of policy makers to ensure that local centres continue to thrive, providing valuable local functions. However, while this appears to be the purpose of retail policy, in reality the implementation and achievement of this policy can prove difficult. The socio-demographic and technological/mobility trends that have facilitated the shift of retailing away from local centres are still present. In addition, major brand retailers continue to prefer to be located within larger centres due to the larger-catchment areas and critical mass that these centres provide. It is for these reasons that retail-led regeneration schemes have been successful in larger centres, as such centres have the ability to attract large amounts of expenditure - the key 'pull factor' for major brand retailers.

The extent to which strategies to re-vitalise more local centres should be reliant on the major brands retailers is therefore questionable. Although there are obvious benefits in attracting major retailers to town centres in order to strengthen the overall competitive and commercial position of an important town centre regeneration project, at the same time the cumulative effect of such projects may undermine existing independent occupiers in relatively weaker, more local centres serving lower-income areas, exacerbating existing uneven wealth distribution.

It must be recognised that retail is still often the primary function of local centres. As patterns of retail behaviour change in relation to changes in mobility and ever more sophisticated consumer choice so the patterns of shopping provision must adapt accordingly. In the retail business town and local centres that do not adapt and compete will quickly decline and even die.

As the level of personal mobility increases so the likelihood that residents will have access to a 'walkable' local centre decreases. This has been recognised by many local authorities. For example, in Wirral the local authority has promoted regeneration initiatives to restructure and reduce in scale its Victorian linear local shopping streets where these are 
showing signs of stress and vacancy along suburban radial routes in the inner areas and in coastal suburbs.

A whole generation of older shop-keepers started their businesses in the pre-supermarket era and are now retiring. As a result the face of local shopping is changing rapidly. Typically an older trader unable to adapt long-established working methods is forced to close a convenience shop when supermarket competition became too strong. However, some independent traders have adapted to rapidly changing conditions and new technology. Some local shops have been taken on by independents catering for specialist markets not as yet addressed by supermarkets and superstores. A proportion of these specialist traders very successfully boost passing trade through internet trading and promotion linked to mail order activity.

In the light of the trends and changes outlined above it is important to many lower-wage communities that local authorities and other public sector regeneration and business partnerships should also consider the potential and role of local centres as part of the wider retail network rather than focussing exclusively on large-scale city centre retail projects. Where successful urban regeneration schemes are able to consolidate and reinforce the retail core of local centres to support a vital 'hub' of local activity including higher density housing, local education and health facilities, mixed uses and development to provide good quality local employment, opportunities are created to support business generation while providing services to meet local retailing need.

Some public sector regeneration initiatives do seek to breathe life into local centres. An example of one of these initiatives is the Under-served Markets Project, which began in March 2003, and is funded by the Neighbourhood Renewal Unit (NRU).

The project is based upon a similar initiative carried out within Harlem USA. It works by attracting significant retail investment into local centres - often those serving inner urban areas housing poor multi-ethnic communities. In the UK, four centres will be identified where there is an above average potential growth in local retail demand over the coming years and retail expenditure is currently leaking out of the areas to other centres. The challenge is to reduce negative perceptions that investors have of these areas, and to attract major retailers into these centres by demonstrating the latent available expenditure within the economy, which is currently leaking to other centres.

Within Harlem the attraction of large 'multiple' retail chains to locate within the local centre project was intended to stimulate the wider economy within the centre as well as stimulating the creation of new local independents. The Harlem project was seen as successful because a greater diversity and quality of retail provision and business investment was attracted to the centre, resulting in a greater degree of consumer choice and new employment opportunities for residents. The high profile private sector investment helped to change the down-at-heel image of this inner urban area as a location for enterprise and also promoted a degree of community pride due to the number of complementary local businesses created following investment by the multiples. 
While it is clear that the Harlem centre project is beneficial to the local economy and provides increased consumer choice, the scheme seeks to exploit the positive aspects of the continued 'march of the brand'.

However, the question must be asked whether there are also negative dimensions to this trend towards global and national branding and commercial organisation.

Branded outlets can act as an anchor for further development (as in the Harlem case) and generally provide a wide choice of goods at reasonable prices, to which residents with limited mobility may not have previously had access. On the negative side of the equation, when regeneration projects are led with branded outlets some independent retailers may be displaced to less competitive locations or be closed down as a result of direct branded outlet/multiple competition. On the positive side of the equation if there is an increased net inflow of expenditure within the local economy as a result of the retail-led regeneration project then new opportunities may arise and there may be increased local employment opportunities.

In planning and designing retail-led regeneration schemes in the UK it is suggested that greater consideration could be given (by local authorities and regeneration agencies) to making physical provision for independent retailers in affordable retail premises. In addition, the provision of 'soft' back-up in terms of appropriate retail training and promotional skills would assist development of an attractive mixed retail offer within the scheme and ensuring consistently high-quality standards for customer care. This type of initiative would also go some way towards addressing the recent 'clone town' critique levelled at centres dominated by the national and global branded outlets that are represented in many towns across the UK and the rest of the world.

A further way in which local centres are currently competing with larger centres and identifying for themselves a specific role and function is through 'differentiation' to cater for local communities which are otherwise underserved by the mainstream retail offer. Many of the communities that are underserved by existing local centres and have disadvantaged access to alternative retail offers include a high proportion of ethnic minorities. Such centres have long had a diverse range of small independent retailers catering for the specialist consumer needs of local residents.

In recent years, some investors and retail operators (such as Wing Yip) have evolved the concept of the corner ethnic store into first generation ethnic supermarkets, providing an increased range and choice of ethnic goods. Owing to the specialist nature of these stores and to the enhanced offer that sound investment has enabled, 'ethnic' multiple stores are now attracting significant trade and attracting expenditure from outside their location's normal catchment area. In such situations, specialist stores providing different products to the same ethnic community such as textiles and jewellery are in turn able to capitalise on spin-off trade improving the vitality and viability of the centre overall. An example of this trend is within Alum Rock Road, Birmingham where current specialist convenience store operators are expanding and seeking to attract trade from beyond the centres immediate catchment area, 
providing associated spin-off benefits to comparison goods operators within the centre.

The development of a specialist role and function for a centre does not necessarily have to be based upon retail provision and can be concentrated upon the wider mixed-use function of a centre. An interesting example of this (also in Birmingham), is the 'Balti Triangle' where ethnic based service provision has led to increased expenditure within a previously run-down area. Asian restaurants and the associated spin-off trade has had the effect of increasing the vitality and viability of the area, in turn increasing both local service and retail facilities for local people.

This trend is demonstrative of how local centres can provide for both local consumer needs and also develop a specialised role and function catering for a wider community and catchment. However, in these cases the centres are able to take advantage of the niche characteristics of the population to provide a local base demand for operation that will help in turn to promote the niche role and function of the centre to a wider audience.

\section{CONCLUSIONS}

This paper has identified a risk that members of disadvantaged communities may in practice be excluded from prestige town centre retail schemes by the cost and difficulty of access and/or by the actual cost of goods and services, inflated by high business rates, lease and city centre operational costs, wages etc. In parallel, the viability of traditional local retail services in lower-income communities (such as the butcher, grocer, greengrocer, newsagent and the like) may be seriously undermined by large format supermarkets that depend on large catchments and car-borne access.

While a range of discount operators such as Aldi, Lidl, Notto and Sommerfield do provide niche services and a wider choice of costeffective goods in some relatively lower-income areas (although not always in the lowest-income areas), commercial income to these national or international operators is exported out of these areas. In contrast independent local businesses may offer a more limited range of goods at higher cost to the consumer but are likely to spend a high proportion of their income on business, household and other services within the community itself.

Both types of retail investment offer advantages to local communities, but as a generalisation the operation of the market tends to favour globalbranded multiple outlets rather than independent traders due to factors such as supply chain management and cost controls, brand recognition, specialist staff training, well-funded advertising and promotion and the ability to undertake structured market presentation and positioning of products/services.

In bringing forward regeneration projects for town centres and lower-income areas, public sector partners (in addition to promoting projects to meet the needs of branded retail outlets) should also consider the potential benefits of engaging with the independent trader sector. 
Retail-led regeneration schemes in town centres and particularly in smaller centres could aim to ensure that a balanced complementary range of goods and services is developed to serve local communities rather than focus exclusively on branded multiple outlets. In many circumstances it would be difficult for this to be achieved solely through unfettered private investment - some pump-primed investment through public sector gap funding or cross-funding through appropriate planning agreements under the Planning and Compensation Act 2004 may be required.

There is also an opportunity to foster and develop a greater number of retail projects that are either community-based or which respond to the special characteristics and needs of the communities in which they are located (e.g. ethnic communities, farm communities) which may then help to rebalance/reverse the present negative expenditure flows out of these neighbourhoods.

In some cases there could be advantages to large-format retailers to develop schemes in such a way as to support a range of interesting and valuable local services that will not generate the higher value returns required by supermarket operators. Some supermarkets have recently started to provide pharmacy/chemists' and optician services because they are able to generate reasonable returns through direct sales or indirectly through attraction of footfall. News agency, off-licence and tobacconist services generate both reasonable income and footfall and have also been taken under the supermarket roof. However, other local services, including personal services such as hairdressing, child-care, car repairs etc. do not offer the same level of cost-benefit and 'fit'. As yet they remain mainly in the hands of individual independents, small chains or community agencies.

Clearly major retail schemes provide new employment in urban areas that may be accessible to residents of deprived areas requiring enhanced job opportunities. In some cases, retail activities are now co-located with leisure activities to complement retail and contribute to an '18-hour' city centre living environment and act as a catalyst in attracting other uses to town centres. In considering the regeneration benefits of these schemes at regional and sub-regional level, it is important to understand the degree to which the strengthened city centre operations has drawn impetus from parallel and related decline in suburban and local locations. Such decline may either be countered by further retail investment (often hampered by restrictive retail planning policies designed to strengthen the focus on major centres) or by development of a specialist niche element as a dominant promotional theme for the local centre. Local planning authorities and regeneration agencies should, therefore, undertake carefully structured assessments prior to taking decisions to move forward with major projects and statutory development allocations for retail and town centre developments. A clear regional and sub-regional framework for local plans will greatly assist in ensuring that adverse domino effects and gravity shifts in retail markets do not accelerate the decline of local centres in ways that conflict with the Government's aims to promote sustainable communities. 


\section{References}

1. Department of the Environment (1993) Revised Planning Policy Guidance 6: Town Centres and Retail Developments, Her Majesty's Stationery Office, UK.

2. Department of the Environment (1996) Revised Planning Policy Guidance 6: Town Centres and Retail Developments, Her Majesty's Stationary Office, UK.

3. Office of the Deputy Prime Minister (2005) Planning Policy Statement 6: Planning for Town Centres, Her Majesty's Stationary Office, UK. 